УДК 342.951: 346.21/346.9

DOI https://doi.org/10.32844/2618-1258.2019.3-1.23

ЗАМРИГА А.В.

\title{
ЗМІСТ АДМІНІСТРАТИВНО-ПРАВОВОГО ЗАБЕЗПЕЧЕННЯ ГОСПОДАРСЬКОЇ ДІЯЛЬНОСТІ В УКРАЇНІ
}

Стаття присвячена формулюванню змісту адміністративно-правового забезпечення господарської діяльності в Україні. З'ясовано, що це сукупність гарантій, засад, способів, засобів та механізмів втручання публічної адміністрації на процес забезпечення державних та суспільних потреб господарюючим суб'єктом чи господарським комплексом матеріального чи не матеріального спрямування на основі виготовлення, реалізації продукції або шляхом надання інших суспільно-корисних послуг. Наголошено, що основними напрямами економічної політики, що визначаються державою, є: структурно-галузева політика; інвестиційна політика; амортизаційна політика; політика інституційних перетворень; цінова політика; антимонопольно-конкурентна політика; бюджетна політика; податкова політика; грошово-кредитна політика; валютна політика; зовнішньоекономічна політика; екологічна політика; соціальна політика захисту прав споживачів, політика заробітної плати і доходів населення, політика зайнятості, політика соціального захисту та соціального забезпечення.

Визначено, що негативне адміністративно-правове забезпечення господарської діяльності в Україні полягає у всебічному тотальному контролі за процесом і процедурами створення, функціонування господарюючих суб'єктів та безпосередньо подальшому жорсткому регулюванню їх взаємовідношень на всіх стадіях діяльності. В Україні діє дуалістична модель адміністративно-правового забезпечення господарської діяльності в Україні, яка полягає у встановлені засад правового регулювання економічного розвитку країни та контролю за їх дотриманням, в тому числі шляхом формування адміністративно-господарського правопорядку.

Зроблено висновок, що зміст адміністративно-правового забезпечення господарської діяльності в Україні - це сукупність гарантій, засад, способів, засобів та механізмів втручання публічної адміністрації на процес забезпечення державних та суспільних потреб господарюючим суб' єктом чи господарським комплексом матеріального чи не матеріального спрямування на основі виготовлення, реалізації продукції або шляхом надання інших суспільно-корисних послуг.

Ключові слова: адміністративно-правове забезпечення, гарантії, господарська діяльність, забезпечення, засади, засоби, зміст, інструменти, способи.

The article is devoted to the formulation content of administrative and legal support of economic activity in Ukraine. It is revealed that this a set of guarantees, principles, methods, means and mechanisms of intervention of public administration on the process of providing state and social needs by the economic entity or economic complex of material or non material purpose on the basis of the manufacture, sale of products or by providing other socio- useful services. It is emphasized that the main directions of economic policy determined by the state are: structural and sectoral policy; investment policy; depreciation policy; institutional transformation policy; pricing policy; antitrust and competition policy; budgetary policy; tax policy; monetary policy; monetary policy; foreign economic policy; environmental policy; social policy of consumer protection, wage and income policy, employment policy, social protection and social security policy.

It is determined that the negative administrative and legal support of economic activity in Ukraine consists in a comprehensive total control over the process and procedures

(C) ЗАМРИГА А.В. - кандидат економічних наук, докторант (Науково-дослідний інститут публічного права) 
of creation, functioning of economic entities and direct further rigid regulation of their relations at all stages of activity. In Ukraine, there is a dualistic model of administrative and legal support of economic activity in Ukraine, which is to establish the principles of legal regulation of economic development of the country and control over their compliance, including through the formation of administrative and economic law.

It is concluded that the content of administrative and legal support of economic activity in Ukraine is a set of guarantees, principles, methods, means and mechanisms of intervention of public administration on the process of providing state and public needs to an economic entity or economic complex of material or non-material direction based on manufacturing, product sales, or through the provision of other community-based services.

Key words: administrative and legal support, content, economic activity, guarantees, means, methods, principles, provision, tools.

Вступ. Сучасна ситуація в Україні потребує трансформаційних процесів, які не тільки налагодять ринкову економічну систему, а й зроблять її ефективною для суспільства. Функція держави при цьому сприяти таким процесам, підтримувати всі сфери народного господарства, забезпечувати задоволення потреб населення [1]. Як здійснюється така діяльність і яким чином вона має бути об'єктивована - це питання, що постійно привертають увагу не тільки науковців, а й нормотворців та публічної адміністрації в цій сфері.

Адміністративно-правове забезпечення господарської діяльності в Україні - специфічний різновид врегулювання взаємовідносин різнорідного походження, що поєднує окрім реалізації публічного адміністрування ще й гарантії такої діяльності, які слугують чинником належного розвитку економічних відносин та зростання економіки країни зокрема. Як і будь-яке юридичне явище, окрім свого смислового трактування, даний концепт має внутрішню будову, яка його характеризує. Основоположним завданням у межах окресленого поля дослідження $є$ з'ясування вищевказаного завдання.

Постановка завдання. До питання визначення змісту адміністративно-правового забезпечення господарської діяльності в Україні провідні вчені безпосередньо не звертались, однак низка науковців досліджували суміжні дотичні явища та процеси. Зокрема, В. Адамовська, Д. Бахрах, В. Галунько, О. Заглада, В. Махінчук, Р. Мельник, В. Пашков, Т. Романенко, С. Щерба та інші.

Результати дослыдження. Словник української мови за 1972 рік визначає термін «зміст» як те, про що говориться, розповідається де-небудь, те, що описується, зображується (у книзі, статті); суть, внутрішня особливість чого-небудь; певні властивості, характерні риси, які відрізняють дане явище, предмет від подібних явищ, предметів; розумна основа, мета, призначення чого-небудь; перелік розділів, частин, оповідань, книги, збірки, рукопису тощо, переважно із вказівкою сторінок, де вони вміщені [2, с. 624].

3 філософської точки зору, зміст - це сукупність елементів, процесів, зв'язків, які становлять даний предмет чи явище [3, с. 419]; те, що складає сутність об’єкта, єдність усіх його складових елементів, його властивостей, внутрішніх процесів, зв'язків, суперечностей і тенденцій [4, с. 378$]$.

Ця визначеність майже ідентична поняттю «сутність» і тісно пов'язана 3 ним. Проте сутність абстрактніша, ширша, ніж категорія «зміст». Нею визначають головний, вирішальний, глибинніший внутрішній зв'язок предметів, які становлять його основу. Поняття «зміст» дещо вужче. Воно також відображає внутрішній і вирішальний зв'язок. Проте не в його найзагальнішому вигляді, а в такому, що реалізується в кожному окремому предметі (групі предметів) на певному етапі розвитку, за певних умов [3, с. 419]. В адміністративній науці цей термін позначає сукупність елементів, процесів, зв'язків, відносин, що утворюють конкретний феномен [5, с. 411].

Адміністративно-правове забезпечення господарської діяльності в Україні - це обов'язок держави по створенню належних умов та порядку ведення господарської діяльності на території України, що реалізується публічною адміністрацією із притаманним їй колом правоможливостей та відповідних повноважень, що об'єктивується системою позитивних та негативних різнобічних різнохарактерних заходів гарантування охорони, захисту та відновлення інтересів суб'єктів господарювання та публічного інтересу українського народу в цілому.

Зміст аналізованого явища може бути юридичним та фактичним. Мова безпосередньо йде про ті складові елементи, що формують основу адміністративно-правового забезпечення господарської діяльності в Україні. Зокрема, фактичний зміст - перелік офіційно встановлених та 
регламентованих необхідних адміністративних дій уповноважених суб'єктів публічної адміністрації відносно конкретної сфери господарства країни. В свою чергу, юридичний зміст:

1) способи та засоби впливу публічної адміністрації на господарську сферу країни - інструментарій адміністративної діяльності;

2) засади, в тому числі гарантії адміністративно-правового забезпечення господарської діяльності в Україні - сукупність принципів та основоположних концепцій відносно дотування, інших видів підтримки господарської діяльності в Україні, захисту, охорони;

3) адміністративно-правові механізми реалізації адміністративно-правового забезпечення господарської діяльності в Україні - процедури реалізації владного впливу а також особливості надання адміністративних послуг в аналізованій сфері. Залежно від різновиду втручання - мінімізованого (як має бути) і всебічно тотального (як зараз $є$ ) - залежить і зміст адміністративно-правового забезпечення господарської діяльності в Україні, який є різним.

Йдеться про функціональну діяльність: 1) суб'єктів повноваження яких реалізовуються в межах законодавчої гілки влади - Верховна рада України; суб'єктів повноваження яких реалізовуються в межах виконавчої гілки влади - Кабінет Міністрів України, профільні міністерства, інші центральні органи виконавчої влади та суб'єкти з делегованими повноваженнями; суб'єктів повноваження яких реалізовуються в межах судової гілки влади - судові органи всіх інстанційних рівнів; суб'єктів повноваження яких не відноситься структурно до жодної з гілок влади Президент України; 2) суб'єктів, повноваження яких прямо стосується адміністративно-правового забезпечення господарської діяльності в Україні - Кабінет Міністрів України, Міністерство економічного розвитку і торгівлі України та державні підприємства, установи, організації, що належать до сфери його управління; Державна служба експортного контролю України, Державна служба України з питань безпечності харчових продуктів та захисту споживачів, Антимонопольний комітет України; суб'єктів, повноваження яких побічно стосується адміністративно-правового забезпечення господарської діяльності в Україні - Міністерство юстиції України, Міністерство внутрішніх справ, Міністерство фінансів України, місцеві державні адміністрації та органи місцевого самоврядування, Фонд державного майна України, Державне агентство резерву України, Національна комісія, що здійснює державне регулювання у сферах енергетики та комунальних послуг, Державне агентство з енергоефективності та енергозбереження України; 3) суб'єктів адміністративно-правового забезпечення у сфері промисловості та виробничих галузей господарства, в сфері паливно-енергетичного комплексу, в агропромисловому комплексі, будівельній сфері, торговельному комплексі, сфері житлово-комунального господарства, сфер використання й охорони природних ресурсів.

Аналізована діяльність публічної адміністрації є: 1) позитивною; б) негативною. Позитивним адміністративно-правове забезпечення господарської діяльності в Україні визначається у випадку саме мінімізованого втручання держави у процеси діяльності господарюючих суб'єктів і зводиться лиш до їх компетентного супроводження та надання можливості автономного вирішення спірних протиріч в межах взаємовідношень. Така діяльність має здійснюватися на стадії підзаконної правотворчості шляхом видання публічною адміністрацією підзаконних нормативно-правових актів, які уточнюють та деталізують закони до стадії їх правозастосування. Далі справа у вирішенні адміністративно-правових спорів має покладатися виключно на систему адміністративних суддів. Однак, суб'єкти господарювання мають бути наділені високим рівнем правової культури і правосвідомості. Держава має здійснювати публічне адміністрування податків та контроль за дотриманням екологічних норм і комплексного антимонопольного регулювання.

Негативне адміністративно-правове забезпечення господарської діяльності в Україні полягає у всебічному тотальному контролі за процесом і процедурами створення, функціонування господарюючих суб'єктів та безпосередньо подальшому жорсткому регулюванню їх взаємовідношень на всіх стадіях діяльності.

Безумовно, державне регулювання $є$ і має бути в аналізованій сфері, однак повинно реалізовуватись інакшим чином. Наша країна поки що не здатна відійти від тотального втручання до виключної підтримки, стимулювання, заохочення та допомоги вітчизняним виробникам продукції та суб'єктам надання суспільно-корисних послуг.

В Україні діє дуалістична модель адміністративно-правового забезпечення господарської діяльності в Україні, яка полягає у встановлені засад правового регулювання економічного розвитку країни та контролю за їх дотриманням, в тому числі шляхом формування адміністративно-господарського правопорядку. 
У статті 9 Господарського кодексу України визначено, що у сфері господарювання держава реалізовує економічну політику, яка розрахована на тривалу перспективу і спрямована на вирішення масштабних економічних та соціальних завдань, завдань культурного розвитку, забезпечення економічної безпеки держави, збереження і примноження її економічного потенціалу і національного багатства, підвищення народного добробуту [6].

Економічна стратегія включає визначення пріоритетних цілей економіки, засобів та способів їх реалізації, виходячи зі змісту об'єктивних процесів і тенденцій, що мають місце в національному та світовому господарстві, та враховуючи законні інтереси суб' єктів господарювання. В свою чергу, економічна тактика - сукупність найближчих цілей, завдань, засобів і способів їх досягнення для реалізації стратегічного курсу економічної політики в конкретних умовах, що складаються в поточному періоді розвитку економіки [6].

Як зазначає Т. Романенко, економічна політика виконує такі функції: 1) створення економічних, правових, політичних, морально-психологічних умов, орієнтованих на надання кожному суб'єкту (індивіду, групі, організації) реальних можливостей для раціонального господарювання; 2) регулювання системи прийняття господарських рішень, для того щоб засоби виробництва належали ефективним власникам, здатним раціонально і прибутково їх використовувати; 3) забезпечення стабільних, максимально передбачуваних і сприятливих макроекономічних умов для господарської діяльності; 4) створення умов і стимулів для ощадливого використання ресурсів, виробництва якісних товарів і послуг; 5) надання суб'єктам господарської діяльності інформації, забезпечення їм можливостей щодо одержання інформації, необхідної для складання і реалізації господарських програм і планів; 6) реалізація раціональної політики доходів, спрямованої на подолання соціально-майнової диференціації за допомогою прогресивного оподатковування, забезпечення достатньої платоспроможності всіх верств і груп населення [7].

Основними напрямами економічної політики, що визначаються державою, є: структурно-галузева політика; інвестиційна політика; амортизаційна політика;політика інституційних перетворень; цінова політика; антимонопольно-конкурентна політика; бюджетна політика; податкова політика; грошово-кредитна політика; валютна політика; зовнішньоекономічна політика; екологічна політика; соціальна політика захисту прав споживачів, політика заробітної плати і доходів населення, політика зайнятості, політика соціального захисту та соціального забезпечення [6].

Відповідно, публічне адміністрування економіки та економічної політики в умовах сьогодення грунтується на:

1) соціально-економічному прогнозуванню та програмуванню: розроблення та виконання державних цільових програм;

2) фінансово-кредитному регулюванню економіки: державний бюджет, податкове регулювання, регулювання державних замовлень, грошово-кредитне регулювання, антиінфляційна політика, інвестиційна політика, тощо;

3) державному регулюванні розвитку науки та техніки, в тому числі інноваційних процесів;

4) державному регулюванні підприємництва, в тому числі державна підтримка малого підприємництва - регулювання ціни і ціноутворення; регламентація засад обліку і статистики; ліцензування окремих видів діяльності (сертифікація, патентування); контроль та надання сервісних послуг по створенню, реєстрації, реорганізації, ліквідації підприємств, установ, організацій; моніторинг за якістю продукції та послуг;

5) державному регулюванні зовнішньоекономічної діяльності: мито й митні податки;

6) регіональній економічній політиці: соціально-економічного розвитку регіонів;

7) соціальній політиці: регулювання доходів населення, обсягу споживання матеріальних благ та послуг, регулювання ринку праці та зайнятості населення;

8) державному регулюванні природоохоронної діяльності: екологічне регулювання, регулювання використання природних ресурсів - моніторинг та охорона державних ресурсів, резервів;

9) розробці законодавства про діяльність галузей промисловості, сільського господарства та агропромислового комплексу, кооперації а також захисту прав споживачів.

Фактично, це сукупність цільових завдань публічної адміністрації, що деталізується комплексом адміністративних дій конкретного ії̈ представника, кожна з якої переслідує конкретну мету по виконанню. $€$ сенс стверджувати, що адміністративно-правове забезпечення господарської діяльності в Україні грунтується на загальних засадах публічного адміністрування економіки загалом, та реалізації економічної політики зокрема. Однак, з поміж іншого, воно має й власні специфічні особливості, що обумовлені зобов'язаннями по гарантійному забезпеченню 
провадження господарської діяльності на території України: 1) всеосяжність врегулювання суспільних відносин та процесів в межах сфери господарювання нормами адміністративного права та їх привілейоване становище відносно інших, галузевих норм; 2) відсутність чітких меж предметного поля, що передбачає включення до аналізованого процесу механізмів галузевого врегулювання питань господарської діяльності; 3) наявність особливого складу публічної адміністрації та співвідношення іiі адміністративної та господарської компетенції; 4) врегулювання загальнонаціональних економічних процесів на ряду із індивідуальними; 5) поєднання контрольних, наглядових, охоронних, захисних, сервісних функцій в діяльності публічної адміністрації; 6) існування специфічного різновиду правопорядку - адміністративно-господарського; 7) наявність адміністративно-правових режимів в сфері господарювання.

Висновки. Усе вищенаведене дає можливість сформулювати висновок, згідно якого зміст адміністративно-правового забезпечення господарської діяльності в Україні - це сукупність гарантій, засад, способів, засобів та механізмів втручання публічної адміністрації на процес забезпечення державних та суспільних потреб господарюючим суб'єктом чи господарським комплексом матеріального чи не матеріального спрямування на основі виготовлення, реалізації продукції або шляхом надання інших суспільно-корисних послуг.

\section{Список використаних джерел:}

1.Адамовська В.С. Механізм державного регулювання економіки та вибір напряму економічної політики в сучасних умовах господарювання. Державне управління: удосконалення та розвиток. 2017. № 4. URL: http://www.dy.nayka.com.ua/?op=1\&z=1063.

2.Білодід І.К. Словник української мови: в 11 т.; АН УРСР, Ін-т мовознавства ім. О.О. Потебні. Т. 3: 3. 1972.744 с.

3.Щерба С.П., Заглада О.А. Філософія : підручник. 5-е вид. К. : Кондор, 2011. 548 с.

4.Спиркин А.Г. Философия : учебник. 2-е изд. М. : Гардарики, 2006. 736 с.

5.Бахрах Д.Н. Административное право России: Особенная часть : учебник для вузов. М. : БЕК, 1997. 330 с.

6.Господарський кодекс України: Закон України від 16.01.2003 № 436-IV. Відомості Верховної Ради України. 2003 р. № 18. стаття 144.

7.Романенко Т.П. Найважливіші функції публічного адміністрування у сфері економіки. Офіційний сайт Запорізької державної інженерної академії. http:/www.zgia.zp.ua/gazeta/ monodrupradmin_405.pdf. 